\title{
BIOSTRATIGRAPHY OF LATE ORDOVICIAN-EARLY SILURIAN STROPHOMENOID BRACHIOPODS FROM ANTICOSTI ISLAND, QUEBEC.
}

DEWING*, Keith, and CALDWELL, W.G.E., Department of Geology, University of Western Ontario, London, Ontario, Canada N6A $5 B 7$.

A combination of shape and form, mode of preservation, and degree of variation makes the strophomenoids one of the more difficult groups of brachiopods to study taxonomically. In turn, taxonomic confusion may explain why the strophomenoids have not been used to the same extent as other groups of brachiopods as a basis for biostratigraphic classification and correlation, and for elucidating biogeographic provincialism. Such conclusions certainly seem warranted following a detailed investigation of the strophomenoids present in the Late Ordovician-Early Silurian carbonate sequence of Anticosti Island, Quebec.

The abundance and superb preservation of Anticosti strophomenoids permit a thorough analysis of external and internal features and the high degree of variation that some of these exhibit. Serial sections are critical to reconstructing the interiors of articulated specimens, establishing taxonomic relationships among discrete valves, and exposing developmental changes in shell structure. When subject to such detailed treatment, at least seventeen genera and twenty-seven species of strophomenoids can be securely identified. Variation among these taxa is such that some features - shape, convexity, ornamentation, and outline of muscle field - hitherto depended upon for taxonomic purposes, have little value in this respect. Other features - pattern of pseudopuncta, form of foramen, pseudodeltidium, chilidium, cardinal process, teeth, dental plates, and socket plates, and presence of ridges and septa bounding and dividing the muscle field - are demonstrably more reliable.

The Ordovician-Silurian boundary in the Anticosti sequence is broadly characterized by change from a plectambonitid-rafinesquinid-strophomenid fauna in the Vaureal Formation (Ashgill), through a plectambonitid-leptaenid-stropheodontidFardenia fauna in the Ellis Bay Formation (uppermost Ashgill), to a leptaenidstropheodontid-Fardenia fauna in the Becscie to Chicotte formations (Llandovery). Considerable overlap occurs between Ordovician and Silurian taxa. The oldest known chonetid and the oldest stropheodontid on Anticosti Island occur in the Vaureal Formation. Plectambonitids and strophomenids are rare in the late Llandovery Jupiter Formation.

Taking a more rigorous biostratigraphical approach, however, distribution of the twenty-seven well-constrained species allows numerous sequential biozones of different type (assemblage, range, overlapping range) to be recognized, up to six of them in the Ashgill section alone. Some zones are distinguished by cosmopolitan species, others by species known from basins well removed from the Anticosti Basin, others again by species seemingly endemic to the Anticosti Basin. These replacements point to a changing pattern of faunal provincialism as Late Ordovician gave way to Early Silurian time. In the Ordovician portion of the section in particular, the biostratigraphic refinement of the potential strophomenoid zones exceeds that of such other brachiopod groups as rhynchonellids or of conodonts. 